\title{
Genetic polymorphism of glutamine synthetase and delta-9 desaturase in families of Pacific oyster Crassostrea gigas and susceptibility to summer mortality
}

\author{
E. David ${ }^{a}{ }^{\star}$, P. Boudry ${ }^{b}$, L. Dégremont ${ }^{b, c}$, A. Tanguy ${ }^{d}$, N. Quéré ${ }^{a, d}$, J.F. Samain $^{e}$ and D. Moraga ${ }^{a}$
}

\begin{abstract}
a'Laboratoire des Sciences de l'Environnement Marin (LEMAR), UMR-CNRS 6539, Institut Universitaire Européen de la Mer, Université de Bretagne Occidentale, Place Nicolas Copernic, 29280, Plouzané, France

'Laboratoire de Génétique et Pathologie, IFREMER La Tremblade, 17390 La Tremblade, France ${ }^{\mathrm{C}}$ Aquaculture Genetics and Breeding Technology Center, Virginia Institute of Marine Science, Gloucester Point, VA23062, USA

dLaboratoire Adaptation et Diversité en Milieu Marin, UMR 7144, Station Biologique, BP. 74, Place Georges Teissier, 29682 Roscoff, France

eUMR Physiologie et Ecophysiologie des Mollusques Marins, IFREMER Centre de Brest, B.P. 70 , 29280 Plouzané, France
\end{abstract}

*: Corresponding author : Elise.David@univ-brest.fr

\begin{abstract}
:
Large-scale mortality events have been observed in Pacific oyster Crassostrea gigas on the west coast of France since the early 1980s, particularly during summer. In order to understand the causes of this mortality, two generations of oysters from single-pair matings were studied in three sites on the French Atlantic coast (Baie-des-Veys, Auray and Ronce-les-Bains). The present paper examines the role of two candidate genes in the susceptibility of oysters to summer mortality, and the selective pressure exerted by such mortality on their polymorphism. Glutamine synthetase (amino-acid metabolism) and delta-9 desaturase (lipid metabolism) genes were studied in the successive generations, using polymerase chain reaction single-strand conformation polymorphism (PCR-SSCP). Observed and expected genotypic frequencies were compared. Three different alleles were detected for the glutamine synthetase gene and two for delta-9 desaturase. Allele $\mathrm{C}$ of glutamine synthetase seemed to be counter-selected in some second generation families. Allele B of delta-9 desaturase gene was potentially counter-selected at Auray in the families showing higher mortality, and strong selection against BB homozygotes was observed. These observations led us to conclude that any selective effect of summer mortality on allele C of glutamine synthetase gene or allele B of delta-9 desaturase gene could be mediated either directly or via linkage to other loci involved in physiological pathways affecting susceptibility.
\end{abstract}

Keywords: Crassostrea gigas; Delta-9 desaturase; Glutamine synthetase; Mortality; SSCP 


\section{Introduction}

3

Coastal ecosystems have been subjected to increased anthropogenic pollution (hydrocarbons, pesticides, nutrient inputs) and other environmental stressors (hypoxia, temperature variations, salinity, etc) in recent decades. Some of these stressors are known to induce modifications in the genetic structure of populations through differential mortality of specific genotypes (Gillespie and Guttman, 1993; Moraga et al., 2002; Tanguy et al., 2002). In fact, it was recently observed that certain individuals within a population may be more vulnerable than others to environmental stressors due to their specific genotypes (Ma et al., 2000). Overall levels of genetic variability can therefore become altered as allele frequencies change (Bickham et al., 2000), which has been observed for enzymatic polymorphisms, extensively studied in marine organisms exposed to contaminants (Moraga and Tanguy, 2000; Moraga et al., 2002; Marchand et al., 2003; Yap et al., 2004). By studying genetic polymorphism in specific candidate genes, genetic biomarkers for sensitivity or resistance to environmental stressors could be characterised in marine populations. Such biomarkers would need to reflect genetic variation in the stress response associated with sensitivity to environmental stress (Depledge, 1996; Forbes and Depledge, 1996). Identification of genetic markers for resistance and/or sensitivity could also be useful as a diagnostic tool to evaluate the consequences of environmental factors for population genetic structure.

The Pacific oyster, Crassostrea gigas, was introduced to French coasts at the end of the 1960s in order to offset high mortalities in the Portuguese oyster Crassostrea angulata (Grizel and Héral, 1991). However, since the 1960s and 1970s in Japan and west coast of the U.S.A. (Beattie et al., 1980), and the early 1980s on the west coast of France (Maurer et al., 1986),

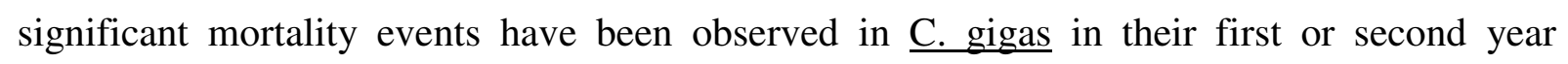
depending on location (Soletchnik et al., 2007). Some mortality events are clearly linked to 
pathogen infection or drastic climatic changes (Soletchnik et al., 1999). In order to better understand the ecological mechanisms leading to these mass mortalities, a multidisciplinary program, called MOREST (“MORtalités ESTivales”), was initiated by IFREMER in 2001. Initial results showed that summer mortality is a multi-factorial phenomenon, resulting from interactions between oysters, their environment and opportunistic pathogens (Samain et al., 2004; Dégremont et al., 2005). Moreover, Dégremont et al. (2007) showed that susceptibility

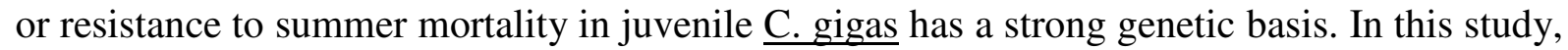
we focus on the genetic impact of summer mortality by following allelic frequencies of two candidate genes through two successive generations of $\underline{C}$. gigas experiencing high levels of summer mortality. Different farming sites were compared to evaluate the potential impact of environmental factors on the relation between mortality and genotypes.

Glutamine synthetase is involved in nitrogen metabolism and glutamine synthesis. It converts glutamate to glutamine which is the most abundant non-essential amino-acid in tissues (Tate et al., 1972). The genes encoding glutamine synthetase have been isolated from several vertebrate species (Hayward et al., 1986; Fahrner et al., 1993) and from invertebrate

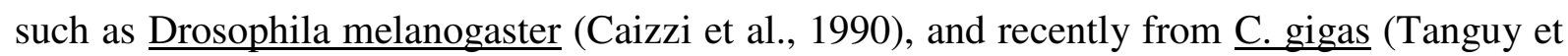
al., 2005a). Glutamine synthetase mRNA is up-regulated in oysters exposed to hydrocarbons, hypoxia or pesticides, and potentially plays an important role in resistance to these stressors (Boutet et al., 2004; Tanguy et al., 2005a,b; David et al., 2005).

Delta-9 desaturase is involved in lipid metabolism. This enzyme catalyses the formation of monounsaturated fatty acids and requires acyl-CoA, NADH, NADH-reductase, cytochrome b5, phospholipid and oxygen as co-factors (Ozols, 1997). Delta-9 desaturase has been extensively studied in mammals, chicken, fishes and insects (Tocher et al., 1998). The

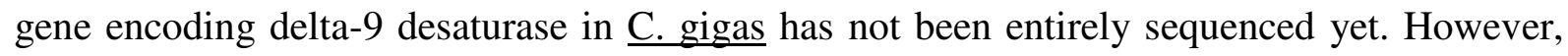
its transcription appears to be down-regulated under experimental hydrocarbon exposure 
101 (Boutet et al., 2004) and up-regulated under experimental hypoxia (David et al., 2005).

102 Fragments of coding sequences were obtained during these exposure experiments. To our 103 knowledge very few studies have been published on glutamine synthetase gene

104 polymorphism. Those that have mostly concern plants (Pratta et al., 2004; Nogueira et al., 105 2005) or, more rarely, human beings (Zhang et al., 2005). To our knowledge, no studies have 106 yet been made on delta-9 desaturase gene polymorphism.

107 The aim of this study was to characterize new genetic markers in the Pacific oyster $\underline{\mathrm{C}}$. 108 gigas, that could be linked with sensitivity to stress, and to investigate whether some 109 genotypes were associated with better survival. We report a potential relationship between the

110 frequency distributions of a specific glutamine synthetase allele and a specific delta-9 111 desaturase allele with summer mortality in oysters. These relationships were investigated in 112 different families and field sites to obtain a clearer picture of the respective roles of genotype 113 and environment.

114

\section{Material and Methods}

Family production and field collection

As part of the MOREST program, a first experimental generation (G1) of C. gigas was

119 bred in 2001 at the IFREMER hatchery in La Tremblade (France). This G1 consisted of 72

120 full-sib families nested within 18 half-sib families produced using 18 males and 72 females as

121 G0 parents (Fig. 1). G1 oysters were subsequently placed in three sites along the French coast:

122 Baie-des-Veys, Auray and Ronce-les-Bains (Fig. 2). Further details about family production,

123 sites and mortality records are described in Dégremont et al. (2005). We selected 6 families

124 showing high survival (average $=95 \%$ ) and 6 families showing low survival (average $=41 \%$ ) 
125 judged by their performances in Auray, which had the highest mortality out of the three sites

126 (Dégremont et al., 2005), and produced 48 G2 'batches' in 2002.

127 Half of these batches were bred from the G1 families showing high survival and the other half

128 from those showing low survival (Fig. 1). Each G2 batch was therefore a form of family

129 obtained by crossing an average of 55 parents overall (proportions of males and females

130 depended on the sex ratio) from two G1 families. We focused on the susceptible G1 families

131 4-16, 14-54, 14-55 and 7-25; their (G0) parents which were males 4, 7 and 14, and females

$13216,25,54,55$; and their (G2) progeny which were the G2 batches J, L and Z (Fig. 3; Table 1).

133 These were chosen on the basis of the families showing the highest mortality rate in G1.

134 The G1 oysters were sampled from all 3 sites in autumn 2001 and the G2 oysters were

135 sampled in autumn 2002. These sites differ notably in temperature dynamics (north to south

136 gradient) and trophic conditions (food availability was the highest in Baie-des-Veys).

137

138

139

140

141

142

143

144

145

146

147

148

149

\section{DNA extraction}

Genomic DNA was extracted from gill tissue. About $100 \mathrm{mg}$ of gill was placed in extraction buffer (0.3 M Tris, $\mathrm{pH} 8,0.02 \mathrm{M}$ ethylene diamine tetra-acetic acid [EDTA], 0.1M $\mathrm{NaCl}$ ) with sodium dodecyl sulphate (SDS) and proteinase $\mathrm{K}$ at final concentrations of $0.6 \%$ and $0.1 \mathrm{mg} \cdot \mathrm{ml}^{-1}$, respectively. The mixture was then incubated at $55^{\circ} \mathrm{C}$ until the tissue was completely dissolved. $\mathrm{NaCl}$ was then added to a final concentration of $1.3 \mathrm{M}$. After homogeneisation, the samples were centrifuged at $3000 \mathrm{~g}$ at $20^{\circ} \mathrm{C}$ for $10 \mathrm{~min}$. The supernatant was taken and two phenol/chloroform/isoamyl alcohol (25:24:1) extractions were performed. DNA was precipitated with absolute ethanol, recovered by centrifugation $30 \mathrm{~min}$ at $12,000 \mathrm{~g}$ at $4^{\circ} \mathrm{C}$, rinsed with $70 \%$ ethanol, dried and dissolved in $1 \mathrm{~mL}$ of TE buffer $(10 \mathrm{mM}$ Tris, $\mathrm{pH} 8,1$ mM EDTA). 


\section{PCR-SSCP analysis}

Exon 6 of the glutamine synthetase gene (GenBank accession no. $\underline{\mathbf{C B 6 1 7 4 0 3}}$ ) was amplified using the forward primer P1 (5'-CTTGCTCTTTTTTTCAGACACATAGA-3') and the reverse primer P2 (5'-GCATTCATCCAGACAGGTAGTCCTTATGAG-3'). A fragment of the delta-9 desaturase gene (GenBank accession no. $\underline{\text { CX069227) }}$ was amplified using the forward primer P3 (5'-TACTGTCTTCTGCTAAACGCCAC-3') and the reverse primer P4 (5'-GTCGTGATATTGAGGTGCCAGCC-3'). All PCR amplification was performed in 25 $\mu \mathrm{L}$ reactions containing $1 \mathrm{X}$ Taq polymerase buffer, $2 \mathrm{mM} \mathrm{MgCl} 2,40 \mu \mathrm{M}$ deoxynucleotides (dNTPs), 10 pmol of each primer, 0.5 units of Taq Uptitherm DNA polymerase (Interchim, Montluçon, France) and about $100 \mathrm{ng}$ of total genomic DNA. After an initial pre-cycle (denaturation $5 \mathrm{~min}$ at $94^{\circ} \mathrm{C}$, primer hybridisation $2 \mathrm{~min}$ at $55^{\circ} \mathrm{C}$, elongation $1 \mathrm{~min} 30 \mathrm{~s}$ at $72^{\circ} \mathrm{C}$ ), 35 amplification cycles were performed as follows: $20 \mathrm{~s}$ at $94^{\circ} \mathrm{C}, 40 \mathrm{~s}$ at $55^{\circ} \mathrm{C}, 1 \mathrm{~min}$ 30s at $72^{\circ} \mathrm{C}$, with a final elongation $10 \mathrm{~min}$ at $72^{\circ} \mathrm{C}$. The PCR products were then combined with $20 \mu \mathrm{L}$ of loading buffer (bromophenol blue, xylen cyanol, saccharose), heated for 5 min to $94^{\circ} \mathrm{C}$, then rapidly chilled on ice to melt and retain single strand DNA. After loading on a neutral $8 \%$ polyacrylamide gel (37.5:1, acrylamide: bisacrylamide), the samples were electrophoresed at constant voltage $(120 \mathrm{~V})$ in $0.6 \mathrm{X}$ TBE buffer, for $15 \mathrm{~h}$ at $10^{\circ} \mathrm{C}$. After electrophoresis, the gels were stained with ethidium bromide and visualised under ultraviolet light. Single strand DNA bands from the PCR products on the gel corresponding to different conformation types were gel-purified by diffusion into water frozen at $-20^{\circ} \mathrm{C}$. The same PCRamplification conditions used for SSCP analysis were also used to recover double strand DNA. PCR products were then purified using a Qiaex II gel extraction kit (Qiagen, Courtaboeuf, France) and cloned into pGEM-T vectors (Promega, Madison, WI, USA). White colonies were grown in LB medium with $100 \mathrm{mg} / \mathrm{l}$ ampicillin and the vector was extracted using an alkaline lysis plasmid minipreparation. The inserts were sequenced using a Li-COR 
175 IR $^{2}$ (Sciencetech Inc., London, Ontario, Canada) and Thermo Sequenase Primer Cycle

176 Sequencing Kit (Amersham Bioscience, Uppsala, Sweden).

177

178

179

180

181

183

184

185

186

187

\section{Results} characterize 3 different alleles which we named A, B and C. The genotypes of the G0 parents

\section{Statistical analysis}

For G1 families observed genotypic frequencies were compared to expected Mendelian genotypic frequencies using $\chi^{2}$ conformity tests implemented with Statistica software (Statsoft). Yates' corrections were made when expected sample sizes ranged from 2 to 5 individuals. Because expected genotypic frequencies could not be estimated for the multiparental G2 batches, we compared genotypic frequencies at Auray and Ronce-les-Bains with those at Baie-des-Veys, where mortality rates were much lower, using contingency table analysis. The standard Bonferroni technique (Lessios, 1992) was used to adjust the significance levels of multiple tests: the predetermined significance level, $\alpha$, was divided by the number of tests, $\mathrm{k}$, to obtain $\alpha^{\prime}$ the corrected significance level $\left(\alpha^{\prime}=\alpha / \mathrm{k}\right.$ where $\alpha=0.05$, $\mathrm{k}=$ number of tests carried out). A multiple correspondence analysis was made on the whole data set using the ADE-4 software package (Chessel et al., 1995), in order to explore possible relationships between glutamine synthetase and delta-9 desaturase genotypes. This kind of factorial analysis allows a graphical representation of several qualitative variables using twoby-two associations.

\section{Glutamine synthetase gene polymorphism}

PCR-SSCP, performed on exon 6 of the glutamine synthetase gene, allowed us to are represented in Table 2. Homozygotes $\mathrm{BB}$ and $\mathrm{CC}$, and heterozygotes $\mathrm{AB}, \mathrm{AC}$ and $\mathrm{BC}$ 
200

201

202

203

204

205

206

207

208

209

210

211

212

213

214

215

216

217

218

219

220

221

222

224

could be clearly scored (Fig. 4). The genotype frequency distributions in the different generations, families/batches and locations are presented in Tables 3 (G1) and 4 (G2) with their respective $\chi^{2}$ values for tests of significant deviations from expectations. G1 families did not show significant differences between observed and expected genotype frequencies based on Mendelian segregation (Table 3, Fig. 5a,b). In the second generation, we compared observed genotypic frequencies at Auray and Ronce-les-Bains sites, where higher mortality rates were observed, with frequencies at Baie-des-Veys, where mortality was lower as the expected values (Table 4, Fig. 5c,d,e). We observed significant differences in batch Z but not in the other batches. In batch Z, the frequency of allele C was lower at Auray and Ronce-lesBains compared to Baie-des-Veys, and even reduced to zero at Ronce-les-Bains.

We also pooled the different G2 batches together and compared the allele frequencies of the three sites to see if there was any overall "site effect". This analysis revealed significant differences between Auray and Baie-des-Veys genotypic frequencies $\left(\chi^{2}=17.59 ; \mathrm{p}=0.0005\right.$; $\alpha^{\prime}=0.013 ; 3$ df) and between Ronce-les-Bains and Baie-des-Veys genotypic frequencies $\left(\chi^{2}=18.12 ; \mathrm{p}=0.0004 ; \alpha^{\prime}=0.013 ; 3 \mathrm{df}\right)$.

The sequences of the different alleles of glutamine synthetase exon 6 , characterized by SSCP, revealed that the sequence of allele A differs from the sequences of the other 2 alleles by 2 nucleotide sequence mutations (amino acids 343 and 345), and one of these results in mutation of the corresponding amino acid. The amino acid cystein (amino acid 343) is replaced by arginin. The nucleotide sequence of allele $\mathrm{C}$ revealed 2 mutations compared with the other 2 alleles, but these modifications are synonymous (amino acids 338 and 339).

\section{Delta-9 desaturase gene polymorphism}

PCR-SSCP performed on a coding fragment of the delta- 9 desaturase gene allowed us to characterize 2 different alleles which we named A and B (Fig. 6). Distribution of observed 
genotypes of the G0 parents is represented in Table 2. The genotypic frequency distributions in the different generations, families, batches and locations are presented in Tables 5 (G1) and 6 (G2) with their $\chi^{2}$ values. Families of the first generation (G1) did not show significant differences between observed and expected Mendelian genotypic frequencies, except for family F7-25 at the Auray site where heterozygote $A B$ was less well represented than expected (Table 5; Fig. 7a,b). We had previously analysed polymorphism of the delta-9 desaturase gene in family F7-25 before field placement in the 3 sites and found no deviation of observed genotypic frequencies from expectations $\left(\chi^{2}=0.02 ; \mathrm{p}=0.89 ; \alpha^{\prime}=0.025 ; 1 \mathrm{df}\right.$, data not shown).

In the second generation, we compared observed genotypic frequencies at Auray and Ronce-les-Bains with those at Baie-des-Veys as the expected. We observed significant differences between Auray and Baie-des-Veys in both batch $\mathrm{Z}$ and batch $\mathrm{J}$ (Table 6; Fig. $7 \mathrm{c}, \mathrm{d}, \mathrm{e})$. No significant differences were observed for the other batches or sites. Bonferroni adjustement removed the significant result for batch $\mathrm{Z}$. We considered it with caution but we did not reject it as the $p$-value was close to the significance level $\left(p=0.02 ; \alpha=0.05 ; \alpha^{\prime}=0.013\right)$.

We also observed a significant decrease in the frequency of allele B at the Auray site in family F7-25 (G1, Table 5, Fig. 7b) and batch Z (G2, Table 6, Fig. 7c). Moreover, no BB homozygotes were observed in batch $\mathrm{Z}$ at any site (Table 6). However, in batch $\mathrm{J}$ at the Auray site, we observed a greater number of individuals carrying allele B compared to Baie-desVeys (Table 6, Fig. 7e).

Pooling the different batches together to compare the 3 sites, we found no deviation between observed genotypic frequencies at Baie-des-Veys and the other 2 sites $\left(\chi^{2}=0.02\right.$; $\mathrm{p}=0.89 ; \alpha^{\prime}=0.025 ; 1 \mathrm{df} ;$ and $\chi^{2}=0.05 ; \mathrm{p}=0.82 ; \alpha^{\prime}=0.025 ; 1 \mathrm{df}$ for Auray and Ronce-les-Bains respectively). 
The sequences of the different alleles characterized by SSCP revealed 2 differences in

nucleotide sequences between alleles A and B (nucleotide 151, amino acid number 50; and nucleotide 157, amino acid number 52 of the amplified fragment). However, these mutations do not change the corresponding amino acids.

Multiple correspondence analysis between genotypes at the two loci

The multiple correspondence analysis performed on the whole dataset did not reveal any significant relationship between individuals carrying glutamine synthetase allele $\mathrm{C}$ and individuals carrying delta-9 desaturase allele B (Fig. 8). This means that individuals carrying

glutamine synthetase allele $\mathrm{C}$ are not likely to carry delta-9 desaturase allele B. However, 260 individuals that were homozygous for the B allele of glutamine synthetase were more 261 frequently homozygous at the delta-9 desaturase locus also.

\section{Discussion}

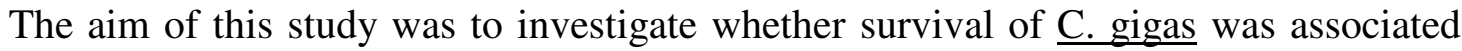
with specific genetic markers, by comparing allelic frequencies in (1) families through three generations and (2) three environmentally different culture sites.

Among methods available to detect polymorphism in DNA sequences, we chose the SSCP approach to detect polymorphism in the coding sequences of the two genes: glutamine synthetase and delta-9 desaturase. We observed deviations from expected Mendelian 271 frequencies after mortality, and differences in genotypic frequencies between sites characterized by high or low summer mortality in some G1 families and/or G2 batches.

273 Several hypotheses could explain these results. Deviations in allele frequencies may be 274 explained by a number of factors, particularly migration, mutation, null alleles, or selection. 
275 Our experimental design eliminated migration. Mutation and null alleles can be eliminated 276 also, because these events are very rare between two successive generations. This leaves only 277 selection as a viable explanation for our results. We analysed polymorphism in family F7-25 278 before mortality and did not observe any deviation from Mendelian expectations. This 279 observation led us to dismiss segregation distortion due to fitness differences at earlier stages.

280 Expected Mendelian frequencies could not be calculated for G2 offspring because many 281 parents (in variable ratios of female and male) were used from each G1 family to produce the 282 G2 and the exact genotypes of each parental individual and their relative contributions to the 283 batch are unknown. For the G2 batches, comparing high mortality sites with a low mortality 284 site allowed us to see how well observed differences in allele frequencies corresponded to 285 differences in mortality assuming only that the allele frequencies were identical at all sites 286 when the batches were planted.

In this work, we chose two genes involved in essential physiological pathways and known to be regulated by a number of environmental parameters. The metabolic functions in which they are involved (nitrogen metabolism, glutamine synthesis and lipid metabolism) are 291 relevant here because of the role of physiological status in susceptibility to summer mortality. With SSCP profiles, we detected three different alleles in exon 6 of the glutamine synthetase gene and analysis of allele segregation in the G1 before field placement showed that observed

294 frequencies did not differ from Mendelian expectations. However, in G2, we observed a 295 strong decrease in the frequency of allele $\mathrm{C}$ in the $\mathrm{Z}$ batch at Auray and Ronce-les-Bains. The 296 frequencies of $\mathrm{AC}$ heterozygotes in both sites and of $\mathrm{BC}$ in Ronce-les-Bains fell to 0 suggesting strong selection against allele $\mathrm{C}$ in the heterozygous condition. Pooling the 298 different batches together and testing for site effects in the second generation, we observed 299 significant differences between observed genotypic frequencies of the glutamine synthetase 
300

301

302

303

304

305

306

307

308

309

310

311

312

gene at Baie-des-Veys and the 2 other sites. However, the fact that the differences in G2 were only observed for the $\mathrm{Z}$ batch and not for the two other batches also indicates an important "family" effect. The differences in counter-selection against heterozygotes among families may be related to the effects of other genes linked to the locus we studied. In any case, it appears that there may be a kind of indirect selection acting on the $\mathrm{C}$ allele possibly involving selection on other linked genes, as suggested by the absence of selection against the $\mathrm{C}$ allele in $\mathrm{G} 1$ and by the fact that allele $\mathrm{C}$ sequencing revealed only synonymous mutations. Alternatively, the variation in genotypic frequencies may not be associated with selection exerted by summer mortality but could be the consequence of a family effect.

The SSCP method also detected 2 different alleles of the coding fragment of delta- 9 desaturase. Genotype frequencies followed Mendelian expectations in the G1 generation except in family F7-25 at Auray, where AB heterozygotes were less frequent than expected. A similar but non-significant trend was observed in Ronce-les-Bains for the same family. In the G2 generation, differences were found in observed frequencies between Auray and Baie-desVeys. In the $\mathrm{Z}$ batch, $\mathrm{AB}$ heterozygotes were significantly less represented in Auray. $\mathrm{A}$ complete absence of homozygote $\mathrm{BB}$ in the $\mathrm{Z}$ batch at any site strongly suggests selection against this genotype. One possible explanation is that the B allele is deleterious, particularly in the homozygous state. When comparing $\mathrm{AB}$ heterozygote frequency and associated mortality in the three sites for G1 families F7-25 and F4-16, we observed a clear relationship between decreasing heterozygosity and increasing mortality rate in both families, with a stronger effect in family F7-25. In G2 batches $\mathrm{J}, \mathrm{Z}$ and $\mathrm{L}$, we also observed that $\mathrm{AB}$ frequency decreased where mortality rates were above $50 \%$ (batches $\mathrm{Z}$ and L in Auray). This tendency seems to suggest that heterozygotes carrying allele B were selected against in the most susceptible families. Furthermore, batch $\mathrm{J}$ showed significantly more AB heterozygotes in 
Auray than in Baie-des-Veys, which could be explained by the fact that mortality was higher in Baie-des-Veys than in Auray for this batch. In the case of delta-9 desaturase, family effect seems to be more important than site effect, as no significant differences of observed frequencies were obtained among sites considering all the batches of the second generation together.

For both genes, heterozygotes seem to be selected against in families showing high mortality. This result is at odds with the common observation of heterozygote advantage in fitness-related traits (Zouros, 1987). Heterozygotes have been frequently reported to use less energy for their metabolism than homozygotes, thus increasing their tolerance to environmental stressors (Hawkins et al., 1989; Holley and Foltz, 1987). In bivalves, David and Jarne (1997) found that heterozygosity at 9 allozyme loci was associated with higher viability. Heterozygote advantage has also been described in relation to enhanced growth rates in clams (Gentili and Beaumont, 1988; Scott and Koehn, 1990). Volckaert and Zouros (1989) also developed a model based on allozyme studies assuming that energy savings attributed to heterozygosity are used to maximize fitness. Nevertheless, it has been shown in many marine species that environmental conditions can select for certain alleles in particular and also decrease heterozygosity at some allozyme loci in populations exposed to pollutants, e.g. in Idotea baltica (De Nicola et al., 1992).

$$
\text { association between glutamine synthetase genotypes containing allele } \mathrm{C} \text { and delta-9 }
$$
desaturase genotypes containing allele B. Individuals carrying glutamine synthetase allele C do not systematically carry delta-9 desaturase allele B. This suggests that there is no linkage between these two genes. However, each gene considered separately could be linked to another nearby gene or locus. Sequence analysis of the 3 glutamine synthetase alleles and the 
2 delta-9 desaturase alleles revealed synonymous mutations in allele $\mathrm{C}$ and allele $\mathrm{B}$ of these

351 genes respectively, compared with the other alleles. The mutations observed in the nucleotide sequence of these alleles could be linked to mutations elsewhere in the coding sequence of these genes or in other linked genes through a hitch-hiking effect (Maynard Smith and Haigh, 1974; Kim and Stephan 2000; Barton, 2000). We analysed the polymorphism of exon 6 of the

355 glutamine synthetase gene because this exon that showed the highest rate of polymorphism in 356 preliminary analyses. The same arguments may also apply to the delta-9 desaturase gene as 357 we have only studied a fragment of the gene. However, a completely different hypothesis 358 which may explain our results is that no direct selection occurred on the glutamine synthetase 359 and delta-9 desaturase loci, but that changes in genotypic frequencies result from a family 360 effect acting during summer mortality. The absence of large differences in the first generation 361 supports this hypothesis and Dégremont et al. (2005) showed that close to $50 \%$ of variation in 362 juvenile oyster survival could be explained by family differences. This family effect on allelic 363 frequencies may be explained at biological level by potential links between the loci we 364 studied and other genes located elsewhere in the oysters genome. Epistatic interactions could 365 be a hypothesis. Family effect we observed on genotypic frequencies could then be a 366 consequence of interactions between glutamine synthetase or delta-9 desaturase alleles and 367 genetic background exerting influence on them.

More generally, in the two genes studied here, changes in genotypic frequencies 370 within a family or batch varied among sites. These family and site effects on genotypic 371 frequencies are consistent with observations by Dégremont et al. (2005) who described a 372 strong family effect on survival and growth of the $\underline{C \text {. gigas families used in the MOREST }}$ 373 program. Dégremont et al. (2005) also showed variation in survival among sites, due to 
environmental conditions, which are consistent with the differences in genotypic frequencies that we observed among sites.

To our knowledge, few studies have dealt with genetic or allozyme polymorphism of glutamine synthetase (Pratta et al., 2004; Nogueira et al., 2005; Zhang et al., 2005) and none with that of delta-9 desaturase. However, allozyme polymorphism at different loci has been examines to test for a possible association with survival in molluscs exposed to various contaminants. In $\underline{\mathrm{C} \text {. gigas, }} 6$ alleles and 5 genotypes at 3 loci ( $\underline{\mathrm{Ak}}, \underline{\mathrm{Pgi}}$ and $\underline{\mathrm{Pgm}})$ were identified as markers of resistance or sensitivity to herbicide stress and differential survival

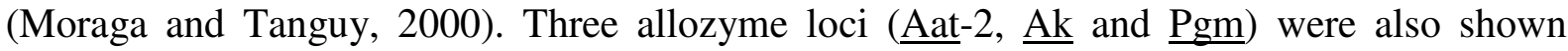
differ in frequency between $\underline{C}$. gigas populations that were resistant or susceptible to TBT

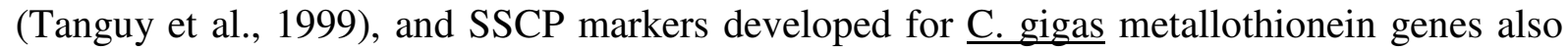
showed a correlation between allele frequencies and resistance to heavy metals (Tanguy et al., 2002). In the present study, no relationship was observed between mortality rates and chemical characteristics of three field sites. This observation suggests that environmental pollutants do not directly contribute to summer mortality at these sites or to the differences among them in allele frequencies. If there is some selection against glutamine synthetase allele $\mathrm{C}$ and delta-9 desaturase allele $\mathrm{B}$, it may therefore not be due to sensitivity to pollutants. Focusing on the causes of mass mortality, Tremblay et al. (1998) studied 4 enzyme alleles in mussels undergoing mass summer mortality, but did not observe any differences in allele frequencies between susceptible and resistant stocks or between one and two-year-old individuals, despite differences in heterozygosity. Xiao et al. (2005) used RAPD markers to investigate the role of genetic factors on scallop mortality in China. They observed reduced genetic diversity in cultured stocks that could result in increased susceptibility to stress leading to increased mortality. 
To conclude, this study has provided new genetic markers, which are in some cases associated with susceptibility to summer mortality in Pacific oyster Crassostrea gigas,

404 frequent in families and sites showing the highest mortality rates, with a stronger family effect 405 than site effect. If there is selection, this seems to occur on other genes or loci to which the studied genes may be linked. Following the genotypic frequencies of the same genes in a third generation could allow us to verify these results. Frequencies of the 2 counter-selected alleles

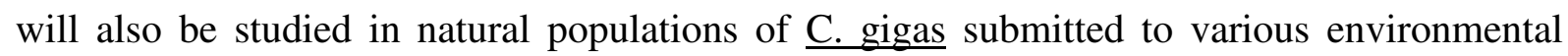

409 stresses in the field in order to obtain complementary results. Finally, other candidate genes 410 involved in other physiological functions are currently being examined for genetic 411 polymorphism in the same families, so as to add depth to the initial exploration described 412 here.

\section{Acknowledgements:}

415 This research program was financially supported by the inter-regional program MOREST 416 (Summer Mortality of juvenile oysters Crassostrea gigas, Grant number 02-2-500022), the 417 PolyGIGAS program of the Bureau des Ressources Génétiques ( $\mathrm{n}^{\circ}$ 05/5210 460/YF), the 418 Marine Genomics Europe Network, the Région Bretagne and the Conseil Général du 419 Finistère. We thank two anonymous reviewers for helpful comments and Helen McCombie 420 for improving the English. 
421

422

\section{References}

Barton, N.H., 2000. Genetic hitchhiking. Phil. Trans. R. Soc. Lond. B 355, 1553-1562.

Beattie, J.H., Chew, K.K., Hershberger, W.K., 1980. Differential survival of selected strains of Pacific Oysters (Crassostrea gigas) during summer mortality. Proc. Natl. Shellfish Assoc. 70, 184-189.

Bickham, J.W., Sandhu, S., Hebert, P.D.N., Chikhi, L., Athwal, R., 2000. Effects of chemical contaminants on genetic diversity in natural populations: implications for biomonitoring and ecotoxicology. Mutation Res. 463, 33-51.

Boutet, I., Tanguy, A., Moraga, D., 2004. Response of the Pacific oyster Crassostrea gigas to hydrocarbon contamination under experimental conditions. Gene 329, 147-157.

Caizzi, R., Bozzetti, M.P., Caggese, C., Ritossa, F., 1990. Homologous nuclear genes encode cytoplasmic and mitochondrial glutamine synthetase in Drosophila melanogaster. J. Mol. Biol. 212, 17-26.

Chessel, D., Dodélec, S., Thioulouse, J., 1995. ADE Version 4: HyperCard Stacks and Programme. Library for the Analysis of Environmental Data. URA CNRS 1451, Université de Lyon 1, 69622 Villeurbanne Cedex (available at http://biomserv.univ-lyon1.fr/ade-4.html).

David, E., Tanguy, A., Pichavant, K., Moraga, D., 2005. Response of the Pacific oyster

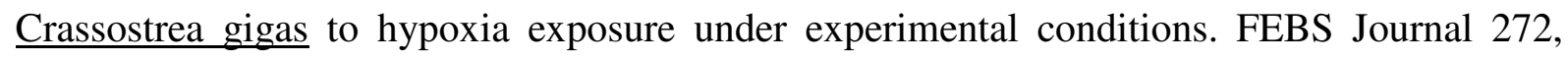
$5635-5652$.

David, P., Jarne, P., 1997. Context-dependent survival differences among electrophoretic genotypes in natural populations of the marine bivalve Spisula ovalis. Genetics 146 (1), 335344.

Dégremont, L., Bédier, E., Soletchnik, P., Ropert, M., Huvet, A., Moal, J., Samain, J.F., Boudry, P., 2005. Relative importance of family, site, and field placement timing on survival, 
445 growth, and yield of hatchery-produced Pacific oyster spat (Crassostrea gigas). Aquaculture $446249(1-4), 213-229$.

447 Dégremont, L., Ernande, B., Bedier, E., Boudry, P., 2007. Summer mortality of hatchery-

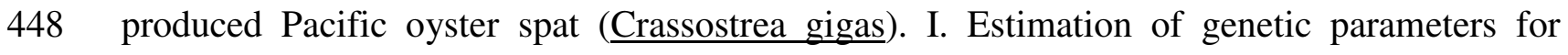
449 survival and growth. Aquaculture 262, 41-53.

450 De Nicola, M., Gambardella, C., Guarino, S.M., 1992. Interactive effects of cadmium and 451 zinc pollution on PGI and PGM polymorphisms in Idotea baltica. Mar. Poll. Bull. 24 (12), $452 \quad 619-621$.

453 Depledge, M.H., 1996. Genetic ecotoxicology: an overview. J. Exp. Mar. Biol. Ecol. 200, 5745466.

455 Fahrner, J., Labruyere, W.T., Gaunitz, C., Moorman, A.F., Gebhardt, R., Lamers, W.H., 1993. 456 Identification and functional characterization of regulatory elements of the glutamine 457 synthetase gene from rat liver. Eur. J. Biochem. 213, 1067-1073.

458 Forbes, V.E., Depledge, M.H., 1996. Environmental stress and the distribution of traits within 459 populations. In: Baird, D.J., Maltby, L., Greig-Smith, P.W., Douben, P.E.T. (Eds), 460 ECOtoxicology: Ecological Dimensions, Chapman \& Hall, London, pp. 71-86.

461 Gentili, M.R., Beaumont, A.R., 1988. Environmental stress, heterozygosity, and growth rate 462 in Mytilus edulis L. J. Exp. Mar. Biol. Ecol. 120, 145-153.

463 Gillespie, R.B., Guttman, S.I., 1993. Correlation between water quality and frequencies of 464 allozymes genotypes in spotfin shiner (Notropis spilopteris) populations. Environ. Poll. 81, $465 \quad 147-150$.

466 Grizel, H., Héral, M., 1991. Introduction into France of Japanese oyster (Crassostrea gigas), J. 467 Cons. Perm. Int. Explor. Mer 47, 399-403.

468 Hawkins, A.J.S., Bayne, B.L., Day, A.J., Rusin, J., Worrall, C.M., 1989. Genotype-dependant 469 interrelation between energy metabolism, protein metabolism and fitness. In: Ryland, J.S,. 
470 Tyler, P.A. (Eds), Reproduction, Genetics and Distributions of Marine Organisms.

471 Fredensborg, Denmark, pp. 283-292.

472 Hayward, B.E., Hussain, A., Wilson, R.H., Lyons, A., Woodcock, V., McIntosh, B., Harris, 473 T.J., 1986. The cloning and nucleotide sequence of cDNA for an amplified glutamine 474 synthetase gene from the Chinese hamster. Nucleic Acids. Res. 14, 999-1008.

475 Holley, M.E., Foltz, D.W., 1987. Effects of multiple-locus heterozygosity and salinity on 476 clearance rate in a brackish-water clam, Rangia cuneata (Sowerby). J. Exp. Mar. Biol. Ecol. $477 \quad 111,121-131$.

478 Kim, Y., Stephan, W., 2000. Joint effects of genetic hitchhiking and background selection on 479 neutral variation. Genetics $155,1415-1427$.

480 Lessios, H.A., 1992. Testing electrophoretic data for agreement with Hardy-Weinberg 481 expectations. Mar. Biol. 112, 517-523.

482 Ma, X.L., Cowles, D.L., Carter, R.L., 2000. Effect of pollution on genetic diversity in the bay 483 mussel Mytilus galloprovincialis and the acorn barnacle Balanus glandula. Mar. Environ. Res. $48450,559-563$.

485 Marchand, J., Tanguy, A., Laroche, J., Quiniou, L., Moraga, D., 2003. Responses of European 486 flounder Platichthys flesus populations to contamination in different estuaries along the 487 Atlantic coast of France. Mar. Ecol. Prog. Ser. 260, 273-284.

488 Maurer, D., Comps, M., His, E., 1986. Caractéristiques des mortalités estivales de l'huître 489 Crassostrea gigas dans le bassin d'Arcachon. Haliotis 15, 309-317.

490 Maynard Smith, J., Haigh, J., 1974. The hitch-hiking effect of a favorable gene. Genet. Res. $491 \quad 23,23-35$.

492 Moraga, D., Tanguy, A., 2000. Genetic indicators of herbicide stress in the Pacific oyster 493 Crassostrea gigas under experimental conditions. Environ. Tox. Chem. 19 (3), 706-711. 
494 Moraga, D., Mdelgi-Lasram, E., Romdhane, M.S., El Abed, A., Boutet, I., Tanguy, A., 2002.

495 Genetic responses to metal contamination in two clams: Ruditapes decussatus and $\underline{\text { Ruditapes }}$ 496 philippinarum. Mar. Environ. Res. 54, 521-525.

497 Nogueira, E.M., Olivares, F.L., Japiassu, J.C., Vilar, C., Vinagre, F., Baldani, J.I., Hemerly, 498 A.S., 2005. Characterization of glutamine synthetase genes in sugarcane genotypes with 499 different rates of biological nitrogen fixation. Plant Science 169, 819-832.

500 Ozols, J., 1997. Degradation of hepatic stearyl CoA $\Delta-9$ desaturase. Mol. Biol. Cell. 8, 22815012290.

502 Pratta, G., Zorzoli, R., Boggio, S.B., Picardi, L.A., Valle, E.M. 2004. Glutamine synthetase 503 levels and related metabolizing enzymes in tomato fruits with different shelf-life. Scientia 504 Horticulturae 100, 341-347.

505 Samain, J.F., Boudry, P., Dégremont, L., Soletchnik, P., Ropert, M., Bédier, E., Martin, J.L., 506 Moal, J., Mathieu, M., Pouvreau, S., Lambert, C., Escoubas, J.M., Nicolas, J.L., Le Roux, F., 507 Renault, T., Burgeot, T., Bacher, C., 2004. Summer mortality in the Pacific oyster Crassostrea 508 gigas, overview of three year results of the cooperative "Morest" project. J. Shellfish Res. 23 509 (1), 309-310.

510 Scott, T.M., Koehn, R.K., 1990. The effect of environmental stress on the relationship of 511 heterozygosity to growth rate in the coot clam Mulinia lateralis (Say). J. Exp. Mar. Biol. Ecol. $512135(2), 109-116$.

513 Soletchnik, P., LeMoine, O., Faury, N., Razet, D., Geairon, P., Goulletquer, P., 1999. 514 Mortalités de l'huître Crassostrea gigas dans le bassin de Marennes-Oléron: étude de la 515 variabilité spatiale de son environnement et de sa biologie par un système d'informations 516 géographiques (SIG). Aquat. Living Resour. 12 (2), 131-143. 
517 Soletchnik, P., Ropert, M., Mazurié, J., Fleury, P.G., Le Coz, F., 2007. Relationships between oyster mortality patterns and environmental data from monitoring databases along the coasts of France. Aquaculture In Press.

Tanguy, A., Fernandez Castro, N., Marhic, A., Moraga, D., 1999. Effects of an organic pollutant (Tributyltin) on genetic structure in the Pacific oyster Crassostrea gigas. Mar. Poll. Bull. 38 (7), 550-559.

Tanguy, A., Boutet, I., Bonhomme, F., Boudry, P., Moraga, D., 2002. Polymorphism of metallothionein genes in the Pacific oyster Crassostrea gigas as a biomarker of response to metal exposure. Biomarkers 7 (6), 439-450.

Tanguy, A., Boutet, I., Moraga, D., 2005a. Molecular characterization of the glutamine synthetase gene in the Pacific oyster Crassostrea gigas: expression study in response to xenobiotic exposure and developmental stage. Biochim. Biophys. Acta 1681 (2-3) 116-125. Tanguy, A., Boutet, I., Laroche, J., Moraga, D., 2005b. Molecular identification and expression study of differentially regulated genes in the Pacific oyster Crassostrea gigas in response to pesticides exposure. FEBS Journal 272, 390-403.

Tate, S.S., Leu, F.Y., Meister, A. 1972. Rat liver glutamine synthetase. Preparation, properties, and mechanism of inhibition by carbamyl phosphate. J. Biol. Chem. 17, 53125321.

Tocher, D.R., Leaver, M.J., Hodgson, P.A., 1998. Recent advances in the biochemistry and molecular biology of fatty acyl desaturases. Prog. Lipid. Res. 37, 73-117.

Tremblay, R., Myrand, B., Sevigny, J.M., Blier, P., Guderley, H., 1998. Bioenergetic and genetic parameters in relation to susceptibility of blue mussels, Mytilus edulis (L.) to summer mortality. J. Exp. Mar. Biol. Ecol. 221, 27-58. 
540 Volckaert, F., Zouros, E., 1989. Allozyme and physiological variation in the scallop

$541 \quad$ Placopecten magellanicus and a general model for the effects of heterozygosity on fitness in 542 marine molluscs. Mar. Biol. 103 (1), 51-61.

543 Xiao, J., Ford, S.E., Yang, H., Zhang, G., Zhang, F., Guo, X., 2005. Studies on mass summer

544 mortality of cultured zhikong scallops (Chlamys farreri Jones et Preston) in China. 545 Aquaculture 250 (3-4) 602-615.

546 Yap, C.K., Tan, S.G., Ismail, A., Omar, H., 2004. Allozyme polymorphisms and heavy metal 547 levels in the green-lipped mussel Perna viridis (Linnaeus) collected from contaminated and 548 uncontaminated sites in Malaysia. Environ. Inter. 30, 39-46.

549 Zhang, B., Yuan, Y., Jia, Y., Yu, X., Xu, Q., Shen, Y., Shen, Y., 2005. An association study 550 between polymorphisms in five genes in glutamate and GABA pathway and paranoid 551 schizophrenia. Eur. Psy. 20, 45-49.

552 Zouros, E. 1987. On the relation between heterozygosity and heterosis: an evaluation of the 553 evidence from marine mollusks. Isozymes 15, 255-270. 
555 Table 1: Mortality of the families used in this study in the 3 field sites.

\begin{tabular}{llccc}
\hline Generation & Family / batch & \multicolumn{3}{c}{ Mortality (\%) } \\
\hline G1 & & Baie-des-Veys & Auray & Ronce-les-Bains \\
G1 & $\mathbf{4 - 1 6}$ & 8.9 & 57.8 & 41.6 \\
G1 & $\mathbf{1 4 - 5 4}$ & 44.4 & 85.2 & 75.3 \\
G1 & $\mathbf{1 4 - 5 5}$ & 24.7 & 82.7 & 66.6 \\
G2 & $\mathbf{7 - 2 5}$ & 20.0 & 56.5 & 58.8 \\
G2 & Z & 6.3 & 64.2 & 40.2 \\
G2 & L & 15.2 & 53.7 & 30.4 \\
\hline
\end{tabular}


556 Table 2: G0 parental genotypes for exon 6 of the glutamine synthetase gene and the delta-9

557 desaturase coding fragment.

\begin{tabular}{ccc}
\hline Parent & Glutamine synthetase genotype & Delta-9 desaturase genotype \\
\hline male 7 & $\mathrm{BB}$ & $\mathrm{AA}$ \\
female 25 & $\mathrm{AB}$ & $\mathrm{AB}$ \\
male 14 & $\mathrm{BB}$ & $\mathrm{AA}$ \\
female 54 & $\mathrm{BB}$ & $\mathrm{AA}$ \\
female 55 & $\mathrm{BC}$ & $\mathrm{AA}$ \\
male 4 & $\mathrm{CC}$ & $\mathrm{AB}$ \\
female 16 & $\mathrm{BB}$ & $\mathrm{AA}$ \\
\hline
\end{tabular}


558 Table 3: Distribution of glutamine synthetase exon 6 genotype frequencies in tested $\mathrm{C}$. gigas G1 families, and comparisons with expected 559 frequencies. Numbers in rounded brackets correspond to degrees of freedom. Numbers in square brackets under $\chi^{2}$ values indicate sample sizes.

560 No significant differences were observed at the $\alpha$ ' significance level.

\begin{tabular}{|c|c|c|c|c|c|c|c|c|c|c|c|}
\hline \multirow[t]{2}{*}{ Family } & \multirow[t]{2}{*}{ Genotype } & \multirow{2}{*}{$\begin{array}{l}\text { Expected } \\
\text { frequency }\end{array}$} & \multicolumn{3}{|c|}{ Baie-des-Veys } & \multicolumn{3}{|c|}{ Auray } & \multicolumn{3}{|c|}{ Ronce-les-Bains } \\
\hline & & & $\begin{array}{l}\text { Observed } \\
\text { frequency }\end{array}$ & $\begin{array}{c}\chi^{2}(\mathbf{d f}) \\
\text { [sample size] }\end{array}$ & $p$-value & $\begin{array}{l}\text { Observed } \\
\text { frequency }\end{array}$ & $\begin{array}{c}\chi^{2}(\mathbf{d f}) \\
\text { [sample size] }\end{array}$ & $p$-value & $\begin{array}{l}\text { Observed } \\
\text { frequency }\end{array}$ & $\begin{array}{c}\chi^{2}(\mathbf{d f}) \\
{[\text { sample size] }}\end{array}$ & $p$-value \\
\hline \multirow[t]{2}{*}{$14-55$} & BB & 0.5 & 0.48 & $0.04(1)$ & 0.99 & 0.38 & $1.69(1)$ & 0.64 & 0.61 & $0.89(1)$ & 0.83 \\
\hline & $\mathrm{BC}$ & 0.5 & 0.52 & {$[23]$} & & 0.62 & [29] & & 0.39 & {$[18]$} & \\
\hline \multirow[t]{2}{*}{$7-25$} & $\mathrm{BB}$ & 0.5 & 0.53 & $0.05(1)$ & 0.97 & 0.50 & $0(1)$ & 1 & 0.52 & $0.05(1)$ & 0.98 \\
\hline & $\mathrm{AB}$ & 0.5 & 0.47 & [19] & & 0.50 & {$[48]$} & & 0.48 & [21] & \\
\hline
\end{tabular}


Table 4: Distribution of glutamine synthetase exon 6 genotype frequencies in tested $\underline{\mathrm{C} \text {. gigas }} \mathrm{G} 2$ batches and comparison of frequencies observed

in Auray and Ronce-les-Bains with frequencies observed in Baie-des-Veys. Numbers in rounded brackets correspond to degrees of freedom. and observed frequencies in Baie-des-Veys, at the $\alpha^{\prime}$ significance level.

\begin{tabular}{|c|c|c|c|c|c|c|c|c|c|}
\hline \multirow[t]{2}{*}{ Batch } & \multirow[t]{2}{*}{ Genotype } & \multicolumn{2}{|c|}{ Baie-des-Veys } & \multicolumn{3}{|c|}{ Auray } & \multicolumn{3}{|c|}{ Ronce-les-Bains } \\
\hline & & $\begin{array}{l}\text { Observed } \\
\text { frequency }\end{array}$ & [sample size] & $\begin{array}{l}\text { Observed } \\
\text { frequency }\end{array}$ & $\begin{array}{c}\chi^{2}(\mathbf{d f}) \\
\text { [sample size] }\end{array}$ & $p$-value & $\begin{array}{l}\text { Observed } \\
\text { frequency }\end{array}$ & $\begin{array}{c}\chi^{2}(\mathbf{d f}) \\
\text { [sample size] }\end{array}$ & $p$-value \\
\hline \multirow[t]{4}{*}{$\mathrm{Z}$} & $\mathrm{AB}$ & 0.06 & & 0.40 & $34.13(3) *$ & $0.00 *$ & 0.50 & $42.03(3) *$ & $0.00 *$ \\
\hline & $\mathrm{AC}$ & 0.23 & [47] & 0.00 & [43] & & 0.00 & [42] & \\
\hline & BB & 0.34 & & 0.56 & & & 0.50 & & \\
\hline & $\mathrm{BC}$ & 0.36 & & 0.05 & & & 0.00 & & \\
\hline \multirow[t]{4}{*}{$\mathrm{L}$} & $\mathrm{AB}$ & 0.11 & & 0.23 & $3.30(3)$ & 0.35 & 0.26 & $4.35(3)$ & 0.23 \\
\hline & $\mathrm{AC}$ & 0.22 & [46] & 0.13 & {$[48]$} & & 0.12 & [42] & \\
\hline & $\mathrm{BB}$ & 0.50 & & 0.50 & & & 0.43 & & \\
\hline & $\mathrm{BC}$ & 0.17 & & 0.15 & & & 0.19 & & \\
\hline \multirow[t]{2}{*}{$\mathrm{J}$} & $\mathrm{AB}$ & 0.29 & & 0.30 & $0.00(1)$ & 1 & 0.26 & $0.03(1)$ & 0.87 \\
\hline & $\mathrm{BB}$ & 0.71 & {$[48]$} & 0.70 & {$[44]$} & & 0.74 & [47] & \\
\hline
\end{tabular}


566 Table 5: Distribution of delta-9 desaturase coding fragment genotype frequencies in tested $\underline{\text { C. gigas }}$ G1 families, and comparisons with expected

567 frequencies. Numbers in rounded brackets correspond to degrees of freedom. Numbers in square brackets under $\chi^{2}$ values indicate sample sizes. *

568 indicates a significant difference between expected and observed frequencies, at the $\alpha$ ' significance level.

\begin{tabular}{|c|c|c|c|c|c|c|c|c|c|c|c|}
\hline \multirow[t]{2}{*}{ Family } & \multirow[t]{2}{*}{ Genotype } & \multirow{2}{*}{$\begin{array}{l}\text { Expected } \\
\text { frequency }\end{array}$} & \multicolumn{3}{|c|}{ Baie-des-Veys } & \multicolumn{3}{|c|}{ Auray } & \multicolumn{3}{|c|}{ Ronce-les-Bains } \\
\hline & & & $\begin{array}{l}\text { Observed } \\
\text { frequency }\end{array}$ & $\begin{array}{c}\chi^{2}(\mathbf{d f}) \\
\text { [sample size] }\end{array}$ & $p$-value & $\begin{array}{l}\text { Observed } \\
\text { frequency }\end{array}$ & $\begin{array}{c}\chi^{2}(\mathbf{d f}) \\
\text { [sample size] }\end{array}$ & $p$-value & $\begin{array}{l}\text { Observed } \\
\text { frequency }\end{array}$ & $\begin{array}{c}\chi^{2}(\mathbf{d f}) \\
\text { [sample size] }\end{array}$ & $p$-value \\
\hline \multirow[t]{2}{*}{$4-16$} & AA & 0.5 & 0.29 & $2.57(1)$ & 0.10 & 0.55 & $0.09(1)$ & 0.76 & 0.44 & $0.25(1)$ & 0.62 \\
\hline & $\mathrm{AB}$ & 0.5 & 0.71 & [14] & & 0.45 & [11] & & 0.56 & [16] & \\
\hline \multirow[t]{2}{*}{$7-25$} & AA & 0.5 & 0.45 & $0.20(1)$ & 0.65 & 0.67 & $5.33(1) *$ & $0.02 *$ & 0.68 & $2.91(1)$ & 0.09 \\
\hline & $\mathrm{AB}$ & 0.5 & 0.55 & {$[20]$} & & 0.33 & {$[48]$} & & 0.32 & {$[22]$} & \\
\hline
\end{tabular}


570 Table 6: Distribution of delta-9 desaturase coding fragment genotype frequencies in tested $\underline{\text { C. gigas }}$ G2 batches and comparison of frequencies observed in Auray and Ronce-les-Bains with frequencies observed in Baie-des-Veys. Numbers in rounded brackets correspond to degrees of freedom. Numbers in square brackets under $\chi^{2}$ values indicate sample sizes. $\Delta$ indicates a significant difference between observed frequencies in observed frequencies in Auray or Ronce-les-Bains and observed frequencies in Baie-des-Veys, at the $\alpha$ ' significance level.

\begin{tabular}{|c|c|c|c|c|c|c|c|c|c|}
\hline \multirow[t]{2}{*}{ Batch } & \multirow[t]{2}{*}{ Genotype } & \multicolumn{2}{|c|}{ Baie-des-Veys } & \multicolumn{3}{|c|}{ Auray } & \multicolumn{3}{|c|}{ Ronce-les-Bains } \\
\hline & & $\begin{array}{l}\text { Observed } \\
\text { frequency }\end{array}$ & $\begin{array}{c}\text { [sample } \\
\text { size] }\end{array}$ & $\begin{array}{l}\text { Observed } \\
\text { frequency }\end{array}$ & $\begin{array}{c}\chi^{2}(\mathbf{d f}) \\
\text { [sample size] }\end{array}$ & $p$-value & $\begin{array}{l}\text { Observed } \\
\text { frequency }\end{array}$ & $\begin{array}{c}\chi^{2}(\mathbf{d f}) \\
\text { [sample size] }\end{array}$ & $p$-value \\
\hline \multirow[t]{3}{*}{$\mathrm{Z}$} & AA & 0.54 & & 0.82 & $6.45(1) *$ & $0.02 \wedge$ & 0.60 & $0.34(1)$ & 0.71 \\
\hline & $\mathrm{AB}$ & 0.46 & {$[46]$} & 0.18 & [33] & & 0.40 & [43] & \\
\hline & $\mathrm{BB}$ & 0 & & $\mathbf{0}$ & & & 0 & & \\
\hline \multirow[t]{2}{*}{$\mathrm{L}$} & AA & 0.75 & & 0.83 & $1.08(1)$ & 0.30 & 0.75 & $0.00(1)$ & 1 \\
\hline & $\mathrm{AB}$ & 0.25 & [48] & 0.17 & [37] & & 0.25 & {$[40]$} & \\
\hline \multirow[t]{2}{*}{$\mathrm{J}$} & AA & 0.79 & & 0.51 & $8.10(1) *$ & $0.01 *$ & 0.68 & $1.50(1)$ & 0.71 \\
\hline & $\mathrm{AB}$ & 0.21 & [48] & 0.49 & {$[45]$} & & 0.32 & [47] & \\
\hline
\end{tabular}


575 Figure 1: Crosses and resulting generations bred as part of the MOREST program and used

576 in the present polymorphism study.

577

578 Figure 2: Location of the 3 field sites in oyster farming areas along the French Channel and

579 Atlantic coasts.

580

581 Figure 3: MOREST families used in this study. Parents (G0) are identified by numbers. G1

582 families are identified by « $\mathrm{x}-\mathrm{y} »$ where $\mathrm{x}$ is the male and $\mathrm{y}$ the female used for the cross. G2

583 batches are identified by letters.

584

585 Figure 4: Diagram of PCR-SSCP profiles obtained for exon 6 of glutamine synthetase in $\underline{\mathrm{C}}$.

586 gigas families. The genotypes are indicated underneath in capitals and the alleles corresponding to each band are given on the left. Each allele is represented by two bands. One band is at the same level for allele A and allele $\mathrm{C}$.

590 Figure 5: Glutamine synthetase genotype frequencies in C. gigas G1 families (A: F14-55; B:

591 F7-25) and G2 batches (C: batch Z; D: batch L; E: batch J). Significant differences between expected and observed frequencies (G1) or between Baie-des-Veys and other sites (G2) are 593 marked *.

595 Figure 6: Diagram of PCR-SSCP profiles obtained for delta-9 desaturase coding fragment in 596 C. gigas families. The genotypes are indicated underneath in capitals and the alleles corresponding to each band are given on the left. Each allele is represented by two bands. 
599 Figure 7: Glutamine synthetase genotype frequencies in C. gigas G1 families (A: F4-16; B: 600 F7-25) and G2 batches (C: batch Z; D: batch L; E: batch J). Significant differences between 601 expected and observed frequencies (G1) or between Baie-des-Veys and other sites (G2) are 602 marked *.

603

604 Figure 8: Multiple correspondence analysis for Crassostrea gigas from all families and all 605 sites, linking glutamine synthetase genotypes with delta-9 desaturase genotypes (GS: 606 glutamine synthetase; D9: delta-9 desaturase). Axis 1: eigen value $=0.536 ; 26.8 \%$ inertia and 607 axis 2 : eigen value $=0.500 ; 25.0 \%$ inertia. As no scale appears on the graph, the ovoid box 608 gives the scale of the axes.

609

610 


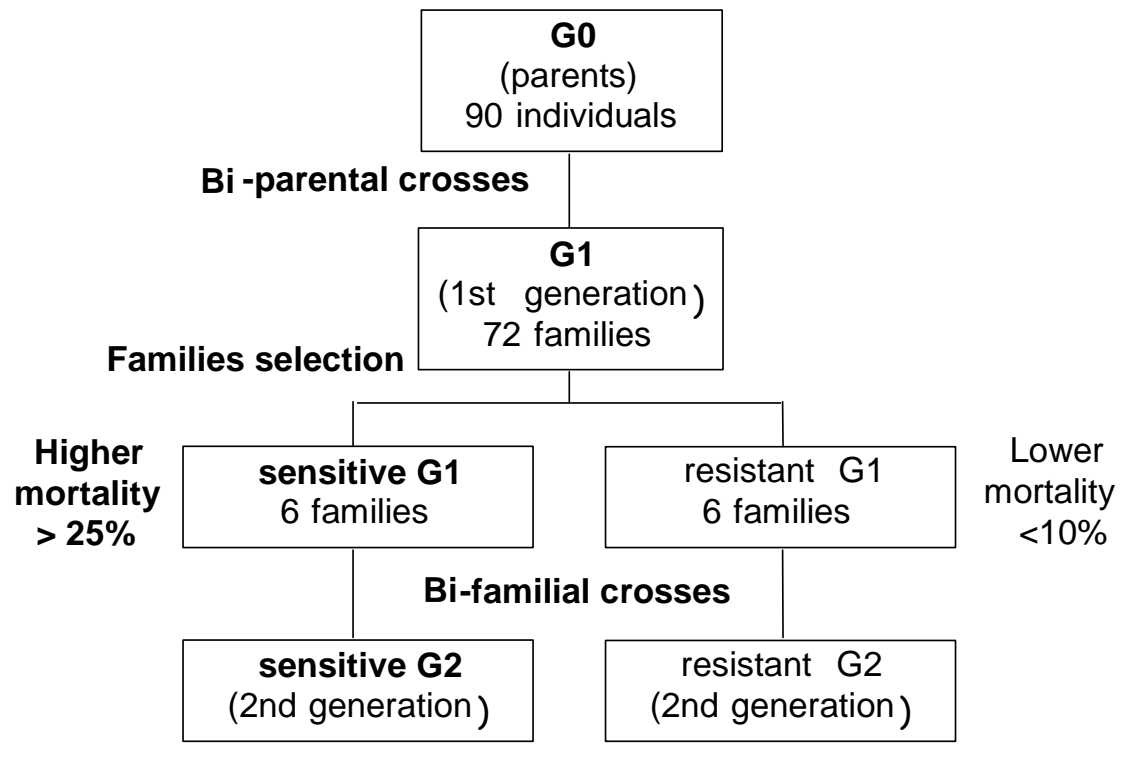

Figure 1

David et al. 


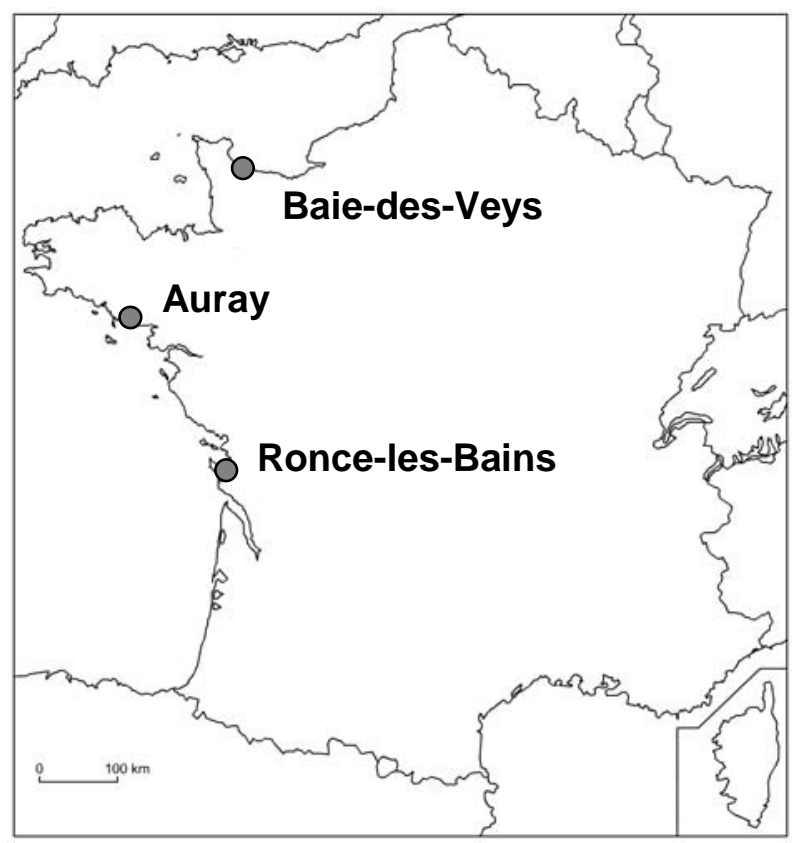

Figure 2

David et al. 


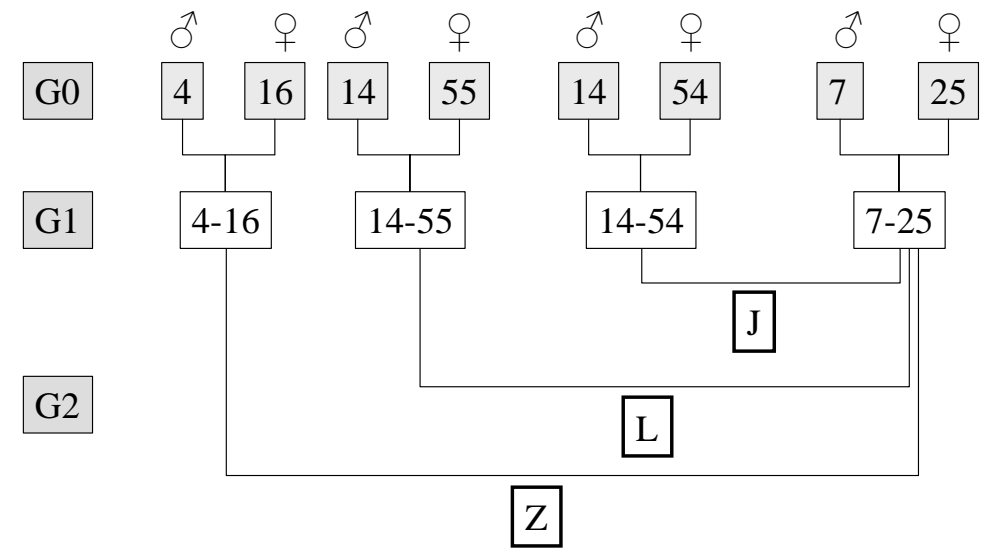

Figure 3

David et al. 
Allele A

Allele B

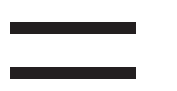

$+$

Allele C

Allele B Allele A or C

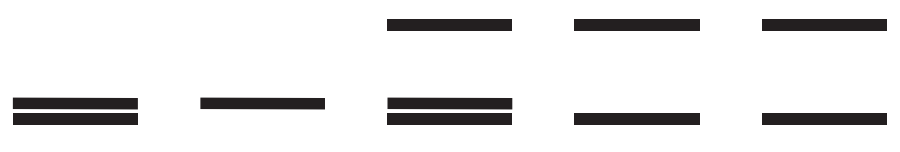

$\mathrm{AB} \quad \mathrm{BB} \quad \mathrm{BC} \quad \mathrm{CC} \quad \mathrm{AC}$

Figure 4

David et al. 
G1

A: F14-55

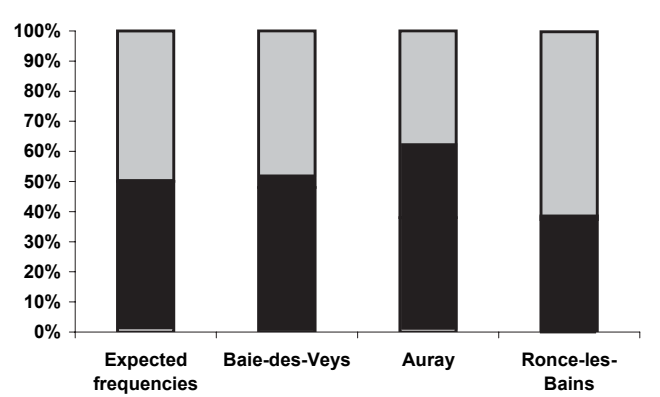

G2 C: batch Z
B: F7-25

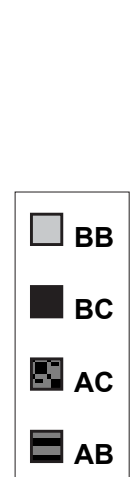

D: batch L

E: batch J
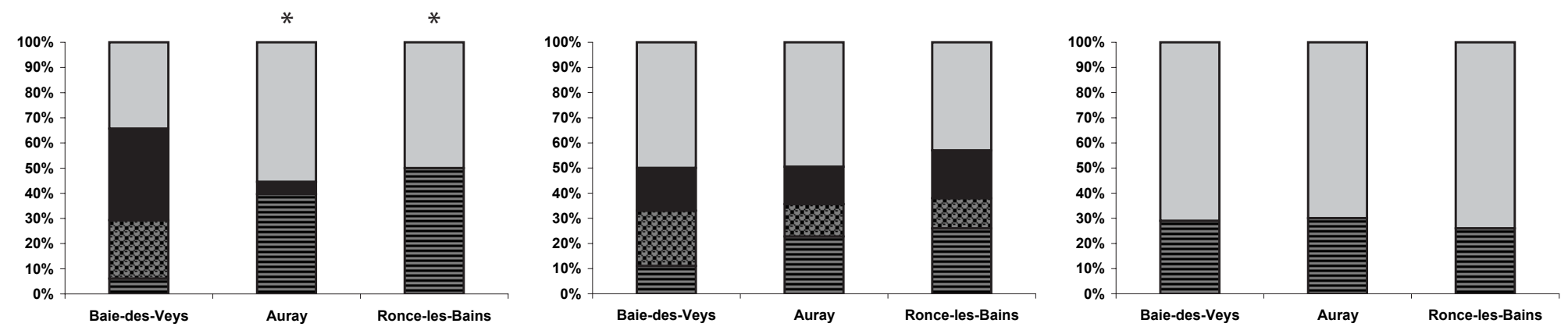

Figure 5

David et al. 
Allele A

Allele B

Allele A

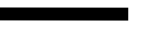

$-$

Allele B

-

AA

$\mathrm{AB}$

\section{Figure 6}

David et al. 
G1 A: F4-16
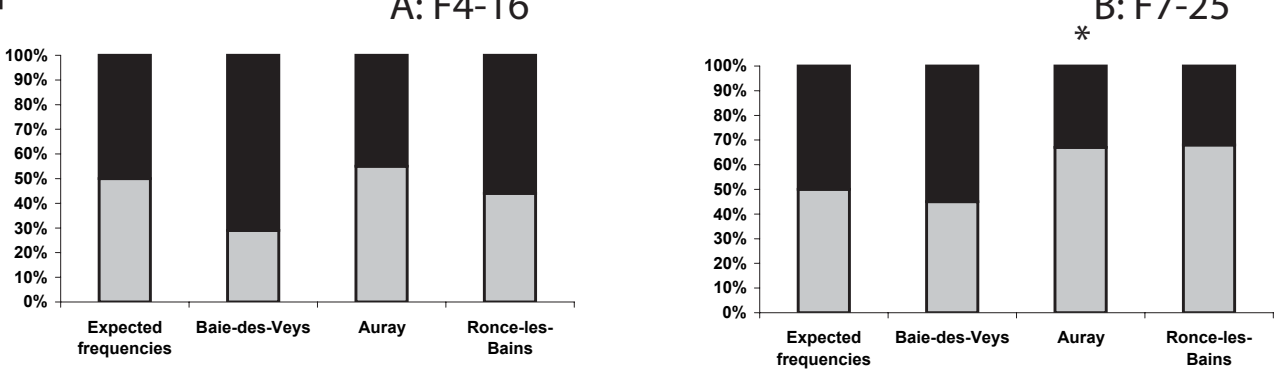

G2

C: batch Z

D: batch L

E: batch J
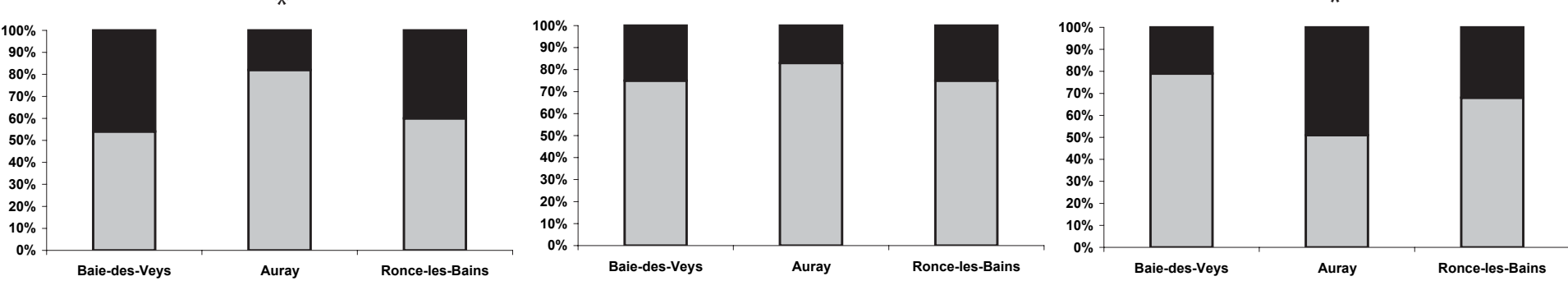

Figure 7

David et al. 


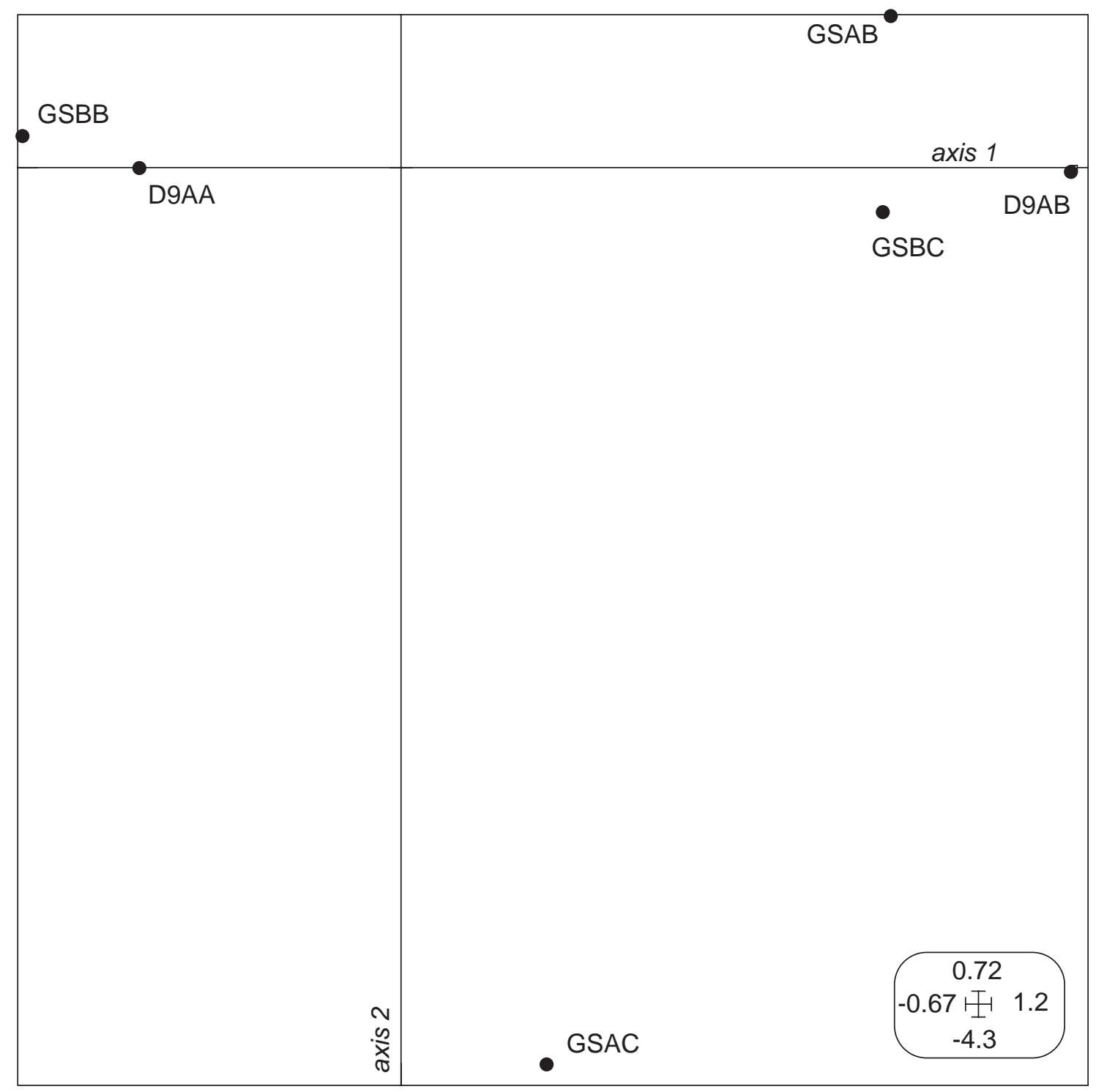

Figure 8

David et al. 